\title{
Training and work process in Multiprofessional Residency in Health as innovative strategy
}

\author{
A formação e o processo de trabalho na Residência Multiprofissional em Saúde como estratégia inovadora \\ La formación y el proceso de trabajo en la Residencia Multiprofesional De Salud como estrategia innovadora
}

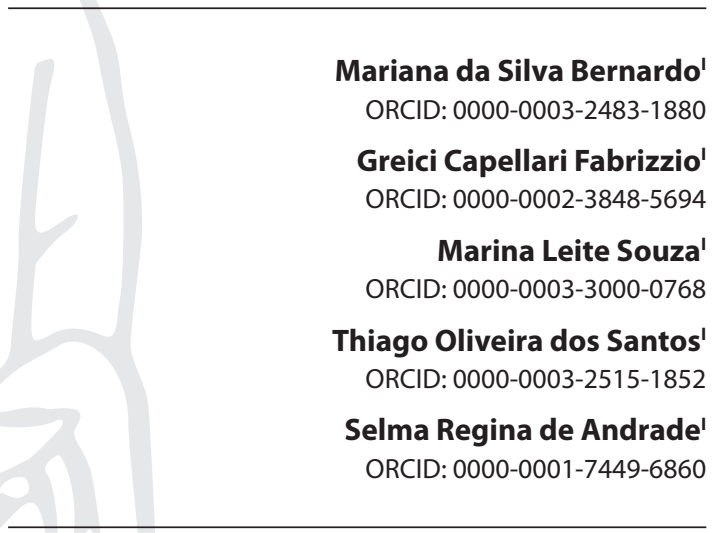

'Universidade Federal de Santa Cataria. Florianópolis, Santa Catarina, Brazil.

How to cite this article:

Bernardo MS, Fabrizzio GC, Souza ML, Santos TO, Andrade SR. Training and work process in Multiprofessional Residency in Health as innovative strategy. Rev Bras Enferm. 2020;73(6):e20190635. doi: http://dx.doi.org/10.1590/0034-7167-2019-0635

Corresponding author: Mariana da Silva Bernardo E-mail: marianabernardo@live.com

EDITOR IN CHIEF: Antonio José de Almeida Filho ASSOCIATE EDITOR: Mitzy Reichembach

Submission: 01-30-2019

Approval: 02-29-2020

\section{ABSTRACT}

Objectives: To reflect about education in health and work process on three programs of multiprofessional residency in Florianópolis/SC. Method: Reflexive study about Multiprofessional Residency Health Programs of Florianópolis. Results: Multiprofessional Residency characterizes training health professionals through service education. Developing these professionals' specialization with assignments that promote professional exercise and magnifies multiprofessional work at the same time, for excellency in unabridged healthcare. Final Considerations: Multiprofessional Residency Programs make interdisciplinary education, sharing knowledge between residents and other professionals stimulating development of innovation skills. Descriptors: Professional Practice; Internship and Residency; Euducation, Graduate; Health Personne; Interprofessional Relations.

\section{RESUMO}

Objetivo: Refletir a formação em saúde e o processo de trabalho nos três programas de residência multiprofissional do município de Florianópolis/SC. Método: Trata-se de um estudo reflexivo acerca dos Programas de Residência Multiprofissional em Saúde do município de Florianópolis. Resultados: A Residência Multiprofissional caracteriza-se por formar profissionais de saúde por meio da educação em serviço. Desenvolvendo a especialização desses profissionais com atribuições que promovem o exercício profissional, e ao mesmo tempo enaltecem o trabalho multiprofissional, para a excelência no cuidado integral à saúde. Considerações finais: Os Programas de Residência Multiprofissional realizam a formação interdisciplinar, partilhando os saberes entre os residentes e demais profissionais e estimulando o desenvolvimento de competências voltadas para a busca pela inovação.

Descritores: Prática Profissional; Internato e Residência; Educação de Pós-Graduação; Pessoal de Saúde; Relações Interprofissionais.

\section{RESUMEN}

Objetivo: Reflexionar sobre la formación en salud y el proceso de trabajo de los tres programas de residencia multiprofesional de la ciudad de Florianópolis, Santa Catarina. Método: Se trata de un estudio reflexivo sobre los Programas de Residencia Multiprofesional de Salud de la ciudad de Florianópolis. Resultados: La Residencia Multiprofesional está caracterizada por la capacitación de los profesionales de la salud mediante la educación en servicio, desarrollando la especialización de dichos profesionales con atribuciones que promueven el ejercicio profesional, y al mismo tiempo exaltan la labor multiprofesional para alcanzar excelencia en la atención integral de la salud. Consideraciones finales: Los Programas de Residencia Multiprofesional llevan a cabo una formación interdisciplinaria, comparten saberes entre los residentes y demás profesionales y estimulan el desarrollo de habilidades volcadas hacia la búsqueda de la innovación.

Descriptores: Práctica Profesional; Pasantía y Residencia; Educacíon Postgrado; Personal de Salud; Relaciones Interprofisionales. 


\section{INTRODUCTION}

Brazilian post-graduation was regulated in the ' 60 s and took an impulse due to strengthen needs of advanced education, associated to demand for professional ability and academic development, in order to promote and potentialize college degree expansion. Post-graduation in Brazil is classified into: stricto sensu and lato sensu. Stricto sensu includes academic master's degree and academic PhD, aiming at an academic career; and professional master's and $\mathrm{PhD}$ degrees. Lato sensu post-graduation is well known for their professional courses and residencies towards professionals linked to companies, third sector services and public organizations ${ }^{(1)}$.

The residency programs, in this context, are separated by sections: health professional residency (single profession) and multiprofessional health. These programs essentially address to education in service. They possess two years minimum length and exclusive dedication system, with a 5.760 hours workload divided into 60 hours a week ${ }^{(2)}$.

Multiprofessional residency is a new model of training, that searches for new horizons, answering health needs at the level of care that is inserted. In this type of residency, there is knowledge integration and different professional expertise sections to qualify the work based upon principles and guidelines of SUS. Therefore, the strategies used are: expanded clinic, singular therapeutic project and essentially multiprofessional care ${ }^{(3)}$.

The Unified Health System (SUS) is responsible for assigning training in the health area. Accordingly, residency courses, in public health emerged as a regent strategy to adapt the training and qualify this field's workers to correspond population's health needs and develop their own system. Corroborating this SUS formation strategy, the work process of multiprofessional residency is aligned with its principles and guidelines, substantiating in locals and regionals realities especially in priority areas.

In this context, continuing education is seen as strategical actions capable of favoring training processes, as well as pedagogical and practical care for better services. Consequently, residency courses, as training strategy, can be considered a form of continuing education. These residencies will demand will power and availability from professionals to change and learn from actions and daily care practice as they may reflect about performed practices, aiming reality change and reframing work processes $^{(3)}$.

Actually, post-graduation performance hopes to rise social awareness the future, according to new times demands, with innovative practices that supply future renewal and innovation for the country ${ }^{(1)}$.

Understanding the importance of performed role played by multiprofessionals residents in professional health training, their experiences in this teaching environment, their potential and fragility, offer elements for improvement of this training process that can contribute for an evaluation of these programs. Strengthening this postgraduation adds substantial value for health work consolidation, with a multiprofessional look for whom care is provided.

Multiprofessional residency programs located in Florianópolis develop partnerships between health and teaching institutions, articulating work of different professionals from Florianopolis city Health Office from the University Hospital Polydoro Ernani from São Thiago, professors of various health sector courses from the Federal University of Santa Catarina and Santa Catarina State University. Out of three residencies, two of them are focused on Primary Health Care, and the other one is focused on Tertiary Health Care.

\section{OBJECTIVE}

To examine health training and work processes on three programs of multiprofessional residencies from Florianopolis/SC.

\section{Multiprofessional Residency Health Programs}

Multiprofessional Residency in Family Health (REMULTISF/USC) was created in 2002 at the Federal University of Santa Catarina. In 2014, the second Multiprofessional Residency in Family Health program was created at the State University of Santa Catarina (REMULTISF/UDESC). Both residencies depend on the City's Health Office partnership for their execution (4). The third Multi Professional Health Integrated Residency (RIMS/UFSC) was created in 2010, associated to the Federal University of Santa Catarina and University Hospital Polydoro Ernani from São Thiago (HU/UFSC).

The Residency Programs are categorized as latu sensu post-graduations, distinguished by service development and monitored by capable professionals, being constantly restructured according to the needs of education and service. To support the educational-care model, the programs count on support of tutors, professors, attending physicians and the institution's employees that act in the healthcare service.

The total workload is divided into practical and theoretical activities. Both training curriculum have active teaching-learning methodologies, problematization methodology and problem-based learning activities. These strategies are made by residents under qualified supervision.

Active methodology provides discussion moments and deepening knowledge in a multiprofessional and interdisciplinary manner, which arise from learning needs based on service practice, agreed among tutors, attending physicians and residents.

The process of the teaching-learning guided by the Pedagogic Political Project of courses predict a structured theory organization of different ways in each one of them. The multiprofessional residency in family health from UFSC is sustained by two units, the theoretical-practical consideration and the education in the workplace. Whilst the multiprofessional internship of family health is arranged in three educational strategies: theoretical, practical and theoretical-practical. And the multiprofessional integrated internship in health from the university hospital is divided into theoretical and theoretical-practical areas.

The three programs rely on classes taught by tutors, professors of promoting institutions and guests. Multiprofessional residency in family health from UDESC depend on participation of attending physicians and professionals inserted in service to lead classes.

Even though multiprofessional residency programs present different methodological designs, there is a consensus related to the defense of continuing education as pedagogical axis, 
participatory and active methodological use. In this process, it's common to three programs effective participation of students and integration among theory, practice and literature, that provides articulation between health system and teaching institutions.

The integration between the areas that create programs takes place both at a theoretical and practical level. At the theoretical level, during classes and at the practical level, during the consultations, case discussions and inter-consultations. Residents remain in the same place of activity throughout their training, but go through more than one field and do internships in other services and levels of care, so they are aware of the reference and counter reference among the various services offered by SUS.

Thus, the work process is based on multiprofessional work, in perspective of building interdisciplinary knowledge and intersectoral practice. Through health promotion strategies, disease and accident prevention, curative care and rehabilitation, at individual, familiar and collective level. And the theoretical educational strategies are guided for the development of multidisciplinary and interdisciplinary practices, in the field of knowledge and integration between professional practices and knowledge through the transverse axis of each program.

The professional improvement of everyday practice is an intention to amplify theoretical knowledge and make practice possible in this profession. From interdisciplinary perspective, programs intend develop from distinguished practice, innovative possibilities for professionals to experience performances in a health environment, considering health needs and a more integrated and articulated vision from SUS users.

Therefore, residency purpose is to train health specialized professionals through service education to act in a multiprofessional way, always following principles and guidelines from SUS, favoring knowledgeable surroundings that aim at discussion and reflection about SUS, and to promote progressive improvement in professional and scientific scope.

Although there is similarity between programs, the number of available positions for each occupation differs (Chart 1).

Chart 1 - Number of open positions in residency program according to profession

\begin{tabular}{|c|c|c|c|}
\hline & REMULTI/UFSC & PREMULTI/UDESC & RIMS/UFSC \\
\hline Physical Education & 02 & 04 & - \\
\hline Nursing & 03 & 16 & 09 \\
\hline Pharmacy & 02 & 04 & 05 \\
\hline Physiotherapy & - & 04 & 02 \\
\hline Speech Therapy & - & - & 02 \\
\hline Nutrition & 02 & 04 & 04 \\
\hline Odontology & 02 & 08 & 02 \\
\hline Psychology & - & 02 & 06 \\
\hline Social Service & 02 & 02 & 06 \\
\hline Number of positions & 13 & 44 & 36 \\
\hline
\end{tabular}

Source: Extracted of call $n^{\circ}$ 008/2018 from Florianopolis city Health Office and from call $n^{\circ}$ 02/2028 of COREMU.

The occupation of nursing, pharmacy, nutrition, odontology and social service dispose of positions in three residency programs, while physical education, physiotherapy and psychology dispose of positions in two programs. Speech therapy is only available in one mentioned program.

\section{Reflecting about training in health residencies}

The main objective of multiprofessional residencies is the education and the training of health professionals. Instigating the specialization of these professionals with attributions that promote the professional care with excellence in integral health care. Involving people, communities, management and health education, aiming at quality for patient's life ${ }^{(4)}$.

For this purpose, an integrated work process with the principles of the Primary Health Care is adopted. The procedure of the work is considered on the subjective dimensions as dynamic, allowing changes in the way of production with the capacity of moving people in their functional core. This subjectiveness creates a care chain established as of connective courses that set the relationship between users and workers aiming the full range of care $^{(5)}$.

A study from 2015 showed residents believe that for quality care development integration between all various sections of health professionals is important. This way, they can say that working in a multiprofessional team requires common objectives, which implies shared commitment and responsibility and, integration among methods used for care. Being essential that role and function of each professional is clear ${ }^{(4)}$.

Multiprofessionalism is understood as the bond between distinct professions that act in an integrated and articulated way to guarantee better integrality of health care $^{(6)}$. Multiprofessionalism happens, mostly, based on case-discussion moments, whether in everyday work life with residents and different sections professionals or in offered classes. It is important to recall that beyond professionals, there is integration with students of different undergraduate courses.

Residents presence in everyday work life of professionals' results in increased team capacity for solving user's health problems. The residents represent support when providing care through knowledge and education exchange, caused by case-discussion and decision-making for health care for users ${ }^{(7)}$.

Alongside professionals that act in health service in which residents are inserted, there are also attending physicians and tutors that are key components to success for professional the training triad.

The attending physicians are professionals that act in health institutions and supervise resident practical activities, to suit them into theoretical-methodological model from residency courses ${ }^{(2)}$. Promoting teaching and learning in practical scenario, improving knowledge, ability and skills learned outside Higher Education Institution (IES) environments, professional experiences references included personal and human aspects, as value, feelings, world vision, that are relevant to health professional training ${ }^{(4)}$. Besides, its strengths the articulation of theory and practice, through problem acknowledgment, searching for explanations or solutions and trying to change reality ${ }^{(3)}$.

It is consistent to reassure that the attending physician acts in a strategic way during teaching processes, occupying a decisive 
position in the functioning and composition of education and health network. This is a great challenge, as besides performing their activity well and supplying service demands, they also need to articulate what is agreed at the University with Health Centers dynamic, stimulating and developing critical awareness in residents, motivating them into acting interdisciplinary and, still, acting as a professional example supporter.

However, this challenge changes into a very valuable experience, promoting constant reflection about developed work and service structure, also awakening interest search for knowledge and work process improvement. Consequently, the acting of attending physicians become more elaborated, resolutive, integral and humanized, which brings more benefits for the service.

Tutors are professionals, with a minimum of three years of professional experience, which function categorizes for realization of academic orientation activities for preceptors and residents ${ }^{(2)}$. The term "tutor" is used to designate roles of those who incentivize "learn to learn" in education context based on problems, which is often confused with preceptor's function ${ }^{(8)}$. Nevertheless, tutors do not work on site the same way attending physicians do in practical field, even though following activities to understand service reality and establishing theoretical-practical mediations between attending physicians and residents is very important ${ }^{(9)}$.

As tutors are generally linked a Higher Education Institution, designating a big part of faculty workload to these institutions, there are difficulties when approaching service reality (9). Although, tutoring is an opportunity for experience exchange, reflection about work process and contribution to new professionals' graduation ${ }^{(10)}$.

However, tutors and attending physicians need proper training, being experts and going through constant qualification relevant to each program methodology, once unfamiliarity about resident professionals' insertion in institutions is disclosed as a problem ${ }^{(9-10)}$.

Attending physicians and tutors hold great quantity of care activities. This way, the professional that acts in learning-teaching process with residents can't fulfill every activity directed towards them. Their withdrawal due great care demand and extensive workload makes discussions of cases and specific themes with residents impossible. This may hamper the bond between them, interfering with the planning and realization of collective and supervised activities ${ }^{(4,9)}$.

The attending physicians and tutor's, along with residents, should provide health institutions reflection and modify, if necessary, their professionals' techniques through professional actions, where the link between theory and practice on daily basis is made, improving actions of the professionals

Residents should obtain and have critical thinking through actions to identify situations that need strategic and revolutionary alternatives in order to make changes that will strengthen SUS.
Is known that the learning process of theoretical activities should not be dissociated from practical activities. Therefore, the intern and the attending physician should comprehend that residents have the capacity to perform in a multidisciplinary and interdisciplinary practice environment. Thus, residents training needs to be understood as a process and not as something isolated as their professional undergraduate degree they can develop their skills on the health system.

When encouraging the development of skills, residency programs make possible for health professionals to feel as if they were students again. This opens space for a pursuit for innovation though theoretical knowledge and care associated to creativity. The innovation brought by the residency program focuses on inserting the interns in the reality of their duty with an interdisciplinary vision pursuing innovation, the solution for scientific and technological problems in loco. For that matter, when we refer to innovation, we embrace not only technology but also the restructuring of work procedures, improvement of the healthcare and insertion of multiprofessional care.

\section{FINAL CONSIDERATIONS}

The Multiprofessional Health Residency, based on its work process, encourages teamwork and interdisciplinarity, which are essential for integrality and resolvability, strengthening SUS and the integration of education, service and community.

The Multiprofessional Health Residency programs in Florianopolis corroborate one of the objectives of health practices, which is the care for an integral health of patients, providing targeted care, focused on their needs according to their reality and social context in an interdisciplinary way among professionals, allowing exchanges among knowledge through activities performed as a team. Besides that, they seek multiprofessional training, in other words, training in which knowledge and information is shared among professionals, while maintaining the individuality and particularity of each one.

Therefore, the Multiprofessional Residency is an opportunity for health professionals to acquire an unabridged view of the health and disease process, to associate with social, cultural and political aspects, in addition to preparing themselves to work with safety and quality in SUS. For attending physicians and tutors, in addition to the experience and knowledge acquired, there is a reflection on the work developed and service structure, besides motivating constant search for knowledge.

Thus, the strengthening of this training process, structured on solid bases of a pedagogical-assistance axis, can bring benefits to future professionals, tutors, service and community. Both in terms of excellence in multiprofessional training, reflecting in the improvement of comprehensive health care, and in the search for innovation and scientific and technological development in loco.

\section{REFERENCES}

1. Rego IJ, MucciJLC. Direito Fundamental à educação capaz de conduzir a um relevante e renovado inovador Brasil do futuro. Rev Dir Soc Pol Públicas [Internet]. 2015 [cited 2018 May 10]. Available form: http://www.unifafibe.com.br/revista/index.php/direitos-sociais-politicaspub/ article/view/68/pdf_37 
2. Ministério de Educação e Cultura (BR) Resolução da Comissão Nacional de Residência Multiprofissional em Saúde CNRMS [Internet]. 2012[cited 2018 May 10]. Available from: http://portal.mec.gov.br/index. php?option=com_docman\&view=download\&alias=15448-resol-cnrms-n2-13abril-2012\&ltemid=30192

3. Silva CT, Terra MG, Kruse MHL, Camponogara S, Xavier MS. Residência Multiprofissional como espaço intercessor para a educação permanente em saúde. Texto Contexto Enferm. 2016;25(1):e276001 doi: 10.1590/0104-07072016000002760014

4. Silva JC, Contim D, OhI RIB, Chavaglia SRR, Amaral SEM. Percepção dos residentes sobre sua atuação no programa da residência multiprofissional. Rev Acta Paul Enferm[Internet]. 2015[cited 2017 Dec 01]28(2):132-8. Available from: http://www.scielo.br/pdf/ape/ v28n2/1982-0194-ape-28-02-0132.pdf

5. Santos DS, Mishima SM, Merhy EE. Processo de trabalho na Estratégia de Saúde da Família: potencialidades da subjetividade do cuidado para reconfiguração do modelo de atenção. Ciênc Saúde Colet. 2018;23(3). doi: 10.1590/1413-81232018233.03102016

6. Araújo TAM, Vasconcelos ACCP, Pessoa TRRF, Forte FDS. Multiprofissionalidade e interprofissionalidade em uma residência hospitalar: 0 olhar de residentes e preceptores. Interface. 2017;21(62):601-3. doi: 10.1590/1807-57622016.0295

7. Domingos CM, Nunes EFPA, Carvalho BG. Potencialidades da Residência Multiprofissional em saúde da família: o olhar do trabalhador de saúde. Interface. 2015;19(55):1221-32. doi: 10.1590/1807-57622014.0653

8. Dias IMAV, Pereira AK, Batista SHSS, Casanova IA. A tutoria no processo de ensino-aprendizagem no contexto da formação interprofissional em saúde. Rev Saúde Debate [Internet]. 2016[cited 2017 Dec 3]40(11):257-67. Available from: http://www.scielo.br/pdf/sdeb/ v40n111/0103-1104-sdeb-40-111-0257.pdf.

9. Lopes CR, Carcereri DL, Minelli DS, Martini D, Kappel EP, Dalmolin IS, et al. Formação de profissionais para atuação no sistema único de saúde: relato de experiência sobre Residência Multiprofissional em Saúde da Família. In: Ferla A, A Série Vivências em educação e saúde [Internet]. 2017[cited 2017 Dec 5]. Porto Alegre: Rede Unida Ed. Available from: http://historico.redeunida.org.br/editora/biblioteca-digital/ serie-vivencias-em-educacao-na-saude/ResidenciasemSaudeeoAprendernoTrabalho.pdf

10. Hospital Universitário Professor Polydoro Ernani de São Thiago. Residência Integrada Multiprofissional em saúde - HU/UFSC [Internet]. 2017[cited 2017 Dec 4]. Available from: http://www.hu.ufsc.br/setores/rims 